\title{
Influence of seasonal changes in climatic conditions on losses at oil tanks filling (on example of the Republic of Bashkortostan)
}

\author{
Alexey Elizaryev ${ }^{1}$,2* $^{*}$ Dmitry Tarakanov ${ }^{1}$, Sergey Aksenov ${ }^{1}$, Denis Tarakanov $^{1}$, Elena \\ Elizareva $^{1}{ }^{3}$, Elina Nasyrova ${ }^{1}$, and Airat Nazyrov ${ }^{4}$ \\ ${ }^{1}$ Ufa State Aviation Technical University, Karl Marx str.12, 450008, Ufa, Republic of Bashkortostan, \\ Russia \\ ${ }^{2}$ Water Problems Institute, Russian Academy of Sciences, Gubkina str.3, 119333, Moscow, Russia \\ ${ }^{3}$ Bashkir state University, Zaki Validi srt.32, 450076, Ufa, Republic of Bashkortostan, Russia \\ ${ }^{4}$ Ufa State Oil Technical University, Kosmonavtov str. 1, 450062, Ufa, Republic of Bashkortostan, \\ Russian Federation
}

\begin{abstract}
Research objective: determining the effect of Influence of seasonal changes on losses at oil tanks filling (on example of the Republic of Bashkortostan). There are many types of oil losses, but most of all is filling loss. They are polluting the environment on the territory of agricultural and oil facilities. They can lead to fire, explosion at oil storage facilities, agricultural enterprises. Method of research: filling loss directly depend on the daily temperature and atmospheric pressure. The work has worked out the values of temperature and atmospheric pressure for the year. Based on the obtained values of air temperature and atmospheric pressure, the volume of big breathing was calculated. Results of the study: the greatest environmental pollution is observed in the summer. In General, there is a uniform dynamics of changes in big breathing throughout the year on the entire territory of the Republic of Bashkortostan.
\end{abstract}

\section{Introduction}

The problem of petroleum products loss is gaining relevance in the modern world. This issue confirmed in the publications of many scientists [1-6]. Oil industry specialist try to reduce losses. The number of losses reaches $1.5 \%$ of all produced oil. During transportation, transfer and storage $75 \%$ of the expensive product is lost as a result of evaporation. The remaining $25 \%$ is lost in accidents and leakages. Filling loss (big breathing) accounting the majority of reservoir losses (more than 50\%). This type of loss is occurs by ejecting air from the tank. The qualitative composition of air is saturated hydrocarbons. Ejections lead to environmental pollution and explosion situations. Every year occur more than 10 emergencies caused by loss of oil products. The main reasons are: wear and tear of equipment, opening of technical devices and violations in the operation of tank farms.

\footnotetext{
*Corresponding author: elizariev@ mail.ru
} 
Filling loss (big breathing) depends on climatic conditions and loading/discharge operations. The tank farm, agricultural facility can be located on the territory with high daily temperature difference and atmospheric pressure. Such conditions lead for changing of losses volume. Storage of oil and oil products takes place in tanks of various types and volumes. The most common tank in Russia and abroad is a vertical stainless steel tank with a capacity of $5,000 \mathrm{~m} 3$. He was chosen as the object of research.

Thus, the main task of work to study the influence of seasonal changes seasonal changes in climatic conditions on the filling loss dynamics (on the example of the Republic of Bashkortostan).

\section{Materials and methods}

At the moment, there are 3 most common methods for quantifying the volume of oil and petroleum products vapors from filling loss (big breathing) Error! Reference source not found.-Error! Reference source not found.:

Methodology of American Petroleum Institute Error! Reference source not found.. Computer program «TANKS» based on this method was developed. It allows determining the volume of oil and petroleum products emissions from reservoirs. For calculating the average annual loss from filling loss, the method suggests using the following formula (1):

$$
\mathrm{L}_{\mathrm{w}}=\mathrm{NH}_{\mathrm{LX}}\left(\frac{\pi}{4} \mathrm{D}^{2}\right) \cdot \mathrm{K}_{\mathrm{N}} \cdot \mathrm{K}_{\mathrm{p}} \cdot \mathrm{K}_{\mathrm{B}} \cdot \mathrm{W}_{\mathrm{V}}
$$

where $\mathrm{N}$ - the rate of turnover of product, rpm/year;

$\mathrm{H}_{\mathrm{LX}}$ - maximum liquid product level in the tank, $\mathrm{ft}$;

$\mathrm{D}$ - inner diameter of the tank, $\mathrm{ft}$;

$\mathrm{K}_{\mathrm{N}}-$ loss factor the product of the turnover;

$\mathrm{K}_{\mathrm{p}}$ - the loss factor, depending on the type of product;

$\mathrm{K}_{\mathrm{B}}$ - the correction factor for the configuration of the breather valve;

$\mathrm{W}_{\mathrm{V}}$ - product vapor density, pound/ft 3 .

The Second method is in Chapter 6 of the German Association of engineer's guidance document VDI 3479 «Control of emissions from tank farms that are not located in oil processing areas» Error! Reference source not found. The document was created in accordance with the recommendations and requirements of the VDI 1000 Error! Reference source not found.. The method Error! Reference source not found. was developed using data obtained from the General project of BMI and DGMK 4509-01 4590-12 Error! Reference source not found.. For calculating the average annual loss from filling loss, the method suggests using the following formula (2):

$$
\mathrm{L}_{\mathrm{B}, \mathrm{a}}=\mathrm{f}_{\mathrm{B}} \cdot 12 \cdot 10^{-3} \cdot \frac{1}{\mathrm{~T}} \cdot \mathrm{p}_{\mathrm{T}} \cdot \overline{\mathrm{M}} \cdot \mathrm{Q}
$$

where $f_{B}$ - degree of saturation;

$\mathrm{T}$ - product temperature in the tank, $\mathrm{K}$;

$\mathrm{p}_{\mathrm{T}}$ - saturated vapor pressure of the product in the tank at the product temperature, $\mathrm{hPa}$;

$\overline{\mathrm{M}}$ - the average molar mass of hydrocarbons in the vapor-air space above the product in the reservoir, $\mathrm{kg} / \mathrm{kmol}$;

$\mathrm{Q}-$ amount of liquid poured per year, $\mathrm{m} 3 /$ year.

The methodology presented in the second edition of the textbook Chugunova P. I. and Novoselov V. F., "Model calculations for the design and operation of tank farms and oil pipelines» Error! Reference source not found.. The authors of the second edition are A. A. Korshak and A. M. Shammazov. For calculating the volume of filling loss is carried out the formula (3): 


$$
G_{s b}=\left[V_{H}-V_{g s} \cdot\left(\frac{P_{2}-P_{1}}{P_{2}-P_{y} \text { pump }}\right)\right] \cdot \frac{P_{y} \text { pump }}{P_{2}} \cdot \rho_{y}
$$

where $V_{H}$ - volume of oil injected into the tank, $\mathrm{m} 3$;

$\mathrm{V}_{\mathrm{gs}}$ - the volume of the gas space in front of the oil pumping, $\mathrm{m} 3$;

$\mathrm{P}_{2}$ - absolute pressure in the gas space at the end of the injection, $\mathrm{Pa}$;

$\mathrm{P}_{1}$ - absolute pressure in the gas space at the beginning of injection, $\mathrm{Pa}$;

$\mathrm{P}_{\mathrm{y} \text { in }}$ - the estimated average partial pressure of oil vapor in the process of filling the tank, $\mathrm{Pa}$;

$\rho_{\mathrm{y}}-$ the density of oil vapor, $\mathrm{kg} / \mathrm{m} 3$.

For comparative analysis of following methods were used data for vertical stainless steel tank with a capacity of 5,000 $\mathrm{m} 3$ (Table 1) and the same climatic conditions.

Table 1. Unified source data for calculation.

\begin{tabular}{|l|l|}
\hline Parameter & Value \\
\hline Inner diameter of the tank & $22.8 \mathrm{~m}$ \\
\hline Internal volume of the tank & $4,864 \mathrm{~m}^{3}$ \\
\hline Installation of breathing valves for overpressure & $1,600 \mathrm{~Pa}$ \\
\hline The installation of the breathing valves on the vacuum pressure & $150 \mathrm{~Pa}$ \\
\hline Radius of the mounting pipe & $0.25 \mathrm{~m}$ \\
\hline The number of respiratory valves & 2 \\
\hline Oil product pumping rate & $400 \mathrm{~m}^{3} / \mathrm{h}$ \\
\hline Oil product injection rate & $600 \mathrm{~m}^{3} / \mathrm{h}$ \\
\hline Oil density & $845.4 \mathrm{~kg} / \mathrm{m}^{3}$ \\
\hline The coefficient of volume expansion of the oil & $0.0008311 / \mathrm{K}$ \\
\hline Average molar mass of product vapors & $54 \mathrm{~kg} / \mathrm{kmol}$ \\
\hline Reduced height of take-off before pumping & $7 \mathrm{~m}$ \\
\hline Reduced takeoff height after pumping & $5 \mathrm{~m}$ \\
\hline Reduced height of take-off before injection & $5 \mathrm{~m}$ \\
\hline Reduced takeoff height after injection & $9 \mathrm{~m}$ \\
\hline
\end{tabular}

The Republic of Bashkortostan lies in a temperate climate zone. The climate is characterized by low humidity, cold winters and warm summers. The variety of terrain, the presence of the Ural ridge, located in the direction of the Meridian, explain the significant differences in temperature and humidity on the territory of the Republic of Bashkortostan (Table 2). In this regard the average annual air temperature in the SouthWestern and Central regions is $+2^{\circ} \mathrm{C},+3^{\circ} \mathrm{C}$, in the North-Eastern and mountainous regions $0^{\circ} \mathrm{C},+1^{\circ} \mathrm{C}$.

Table 2. Data on temperature and atmospheric pressure (for 2018 year).

\begin{tabular}{|l|l|l|l|l|l|l|l|l|l|}
\hline \multirow{2}{*}{$\begin{array}{l}\text { Weather } \\
\text { stations }\end{array}$} & $\begin{array}{l}\text { Winter period } \\
t_{a .},\end{array}$ & $\begin{array}{l}P_{\mathrm{cp} .}, \\
\mathrm{kPa}\end{array}$ & $\begin{array}{l}{ }_{{ }_{a} .} \mathrm{C} \\
{ }^{\circ} \mathrm{C}\end{array}$ & $\begin{array}{l}P_{\mathrm{cp} .}, \\
\mathrm{kPa}\end{array}$ & $\begin{array}{l}t_{a .}, \\
{ }^{\circ} \mathrm{C}\end{array}$ & $\begin{array}{l}P_{\mathrm{cp} .}, \\
\mathrm{kPa}\end{array}$ & $\begin{array}{l}t_{a .}, \\
{ }^{\circ} \mathrm{C}\end{array}$ & $\begin{array}{l}P_{\mathrm{cp} .}, \\
\mathrm{kPa}\end{array}$ \\
\hline Yanaul & -11.8 & 101.6 & 1.1 & 100.3 & 17.1 & 100.3 & 4.1 & 100.7 \\
\hline Duvan & -12.6 & 98.6 & 0.9 & 97.4 & 16.0 & 97.2 & 2.8 & 97.8 \\
\hline Ufa & -11.4 & 101.6 & 2.3 & 100.3 & 18.3 & 99.9 & 4.5 & 100.7 \\
\hline Zilair & -13.5 & 96.5 & 1.8 & 95.4 & 17.1 & 95.2 & 3.0 & 95.9 \\
\hline
\end{tabular}


When analyzing the dynamics of oil vapors due to big breaths, the reservoirs located in these areas are considered.

\section{Results and discussion}

Comparative analysis of the results of calculations using the methods [10,11,12] was performed (Fig. 1). Method [12] was taken as the standard. Method [12] uses a greater number of optional input parameters. This has a positive effect on the accuracy of the results.

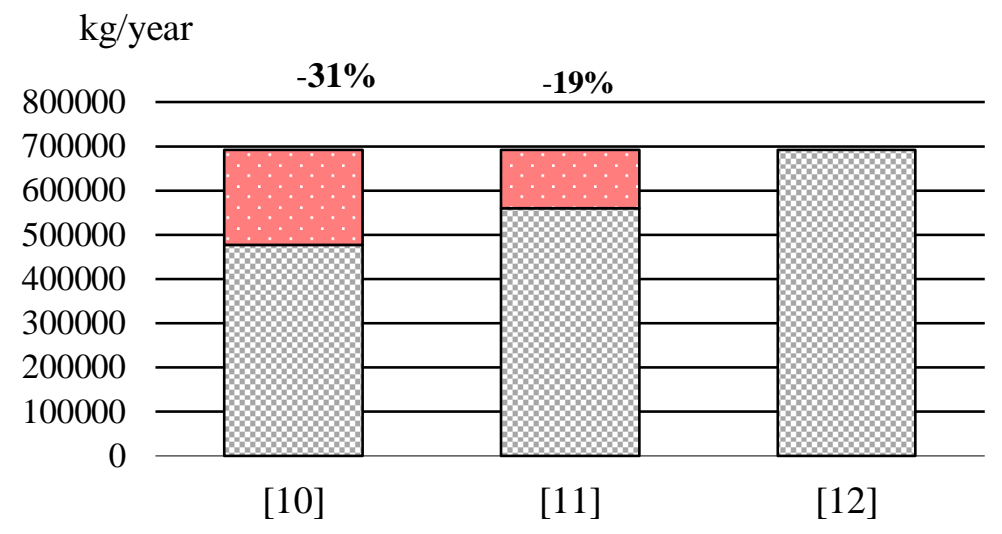

Fig. 1. Comparatve analysis of the results of calculating the volume of losses from filling loss by methods [10-12].

Comparative analysis in Fig. 1 showed a significant difference between the results of calculating the losses volume from filling by three methods. This is due to the amount of raw data. The losses calculated by the method [10] differ from the standard by more than $30 \%$. Further using this method for the analysis of oil vapors volume from filling loss is impractical. The method of calculating the average annual losses affected the difference in the results of calculations using the methods [11] and [12]. In the first case, the calculation consists of losses sum as a result of individual operations. In the second case, the calculation is based on multiplying the volume of losses from one filling loss per day by the number of days per year. The most suitable method for performing the task is the method [12]. For calculation it uses the maximum and minimum temperatures per day. This plays a key role in analyzing the dynamics of losses.

Data on the temperature regime and the average monthly atmospheric pressure for 2018 from the weather stations Yanaul, Ufa, Zilair and Duvan (Table. 2) helped to perform the calculation of losses from big breathing (filling loss) in the considered areas in the winter, spring, summer and autumn climatic periods (Fig. 2).

Fig. 2 showed a significant difference between the volume of big breathing (filling loss) during the year in different regions of the Republic of Bashkortostan. The greatest losses from filling loss are observed in the summer (more than 3,000 $\mathrm{kg}$ per breath). They have the main share in the total volume of evaporation. It tells about the pollution of the environment to a greater extent in the summer. The value of winter losses is lower by more than $10 \%$. The values of losses in the spring and autumn periods do not have a significant difference. The amount of loss from filling changes by about $6 \%$ every three months. Total volumes of filling loss in the territory of the considered areas have no fundamental differences (no more than 5\%). Ufa city has the largest volume of total losses and, consequently, the highest environmental pollution. In general, the losses volume from big 
breathing (filling loss) on the territory of considered areas for the same time periods have similar values. This indicates a uniform dynamics of change throughout the year on the entire territory of the Republic of Bashkortostan.

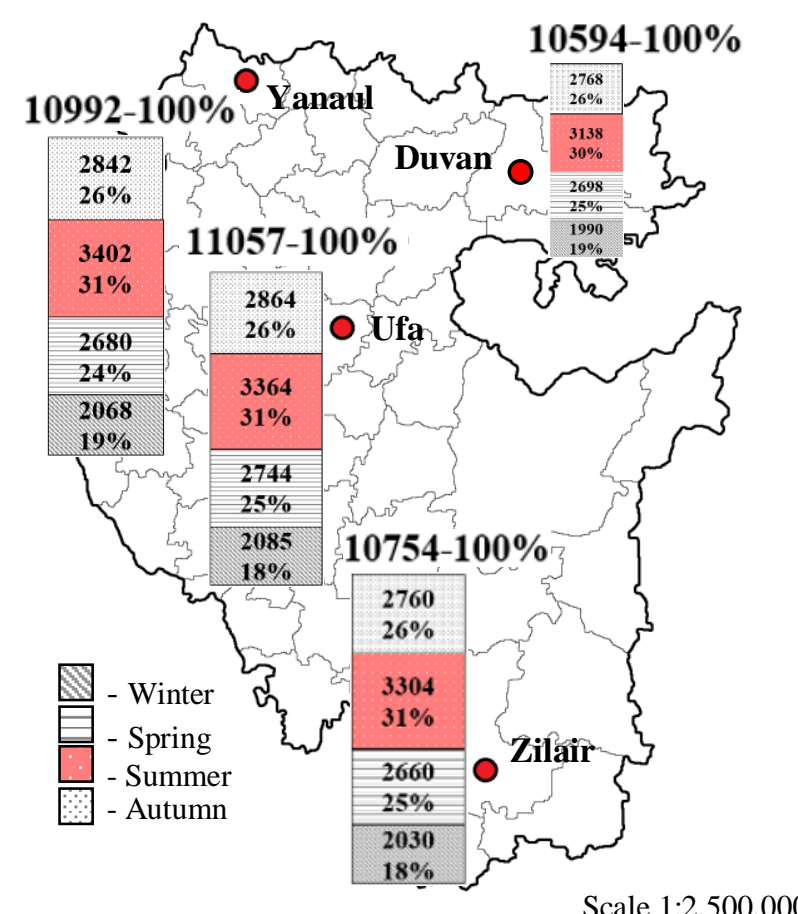

Fig.2. The value of filling loss (in $\mathrm{kg}$ ) in the considered areas in different time.

\section{Conclusion}

The analysis of methodological approaches for the quantitative assessment of big breathing volume was carried out. Based on the obtained results was choosing a more suitable method. The calculation of the filling loss magnitude in the winter, spring, summer and autumn climatic periods for three regions was performed. The results showed a single trend of big breathing volume changes during year on the territory of the Republic of Bashkortostan. This indicates the greatest pollution of the environment during the summer period and increases the risk of fire and explosion hazardous situations.

\section{References}

1. M. Farhana, M. Al-Jumialya, A. Al-Muhammadia, A. Ismaila, Development of a New Method for Reducing the Loss of Light Hydrocarbons at Breather Valve of Oil Tanks, 14,1 471-478 (2017) DOI: 10.1016/j.egypro.2017.11.061

2. A. Bahadori, A. Baghban, M. Bahadori, T. Kashiwao, M. Vafaee Ayouri, Estimation of emission of hydrocarbons and filling losses in storage containers using intelligent models, 145-152 (2016) DOI: 10.1080/10916466.2015.1122631

3. Y. Liang, Acta Metrologica Sinica, 39(6), 857-861 (2018) DOI: 10.3969/j.issn.10001158.2018.06.20 
4. V. Pshenin, N. Zaripova, K. Zaynetdinov, Petroleum Science and Technology, 37(24), 2435- 440 (2019) DOI: 10.1080/10916466.2019.1655442

5. D. Littlejohn, D. Lucas, Tank Atmosphere Perturbation: A Procedure for Assessing Flashing Losses from Oil Storage Tanks, 360-365 (2003) DOI: 10.1080/10473289.2003.10466158

6. G. Elizaryev, R. Maniakova, E. Gabdulkhakov, A. Elizareva, A. Longobardi, A. Nurutdinov, R. Khakimov, Numerical simulation of oil spills based on the gnome and adios, 7, 24-27 (2018) DOI: 10.14419/ijet.v7i2.23.11876

7. I. Afanasev, T. Volkova, A. Elizaryev, Russian Federation WSEAS transactions on environment and development 10(1), 405-416 (2014)

8. VDI 1000. VDI-Richtlinienarbeit - Grundsätze und Anleitungen, (2010)

9. BMI-DGMK Gemeinschaftsprojekt 4590-01 bis 4590-12 „Messen und Ermittlung von Kohlenwasserstoff-Emissionen bei Lagerung, Umschlag und Transport von Ottokraftstoffen und Prüfen von Verfahren zur Beherrschung dieser Emissionen“, Teil 1: Zusammenfassender Bericht des Gesamtprojekts, Teil 2: Berichte zu den Teilob-jekten.

10. API Manual of Petroleum Measurement Standards, Chapter 19 - Evaporative-loss Measurement, Section 1 - Evaporative Loss from Fixed-Roof Tanks, Third Edition, March, (2002)

11. VDI 3479: Emissionsminderung. Raffinierieferne Mineralöltanklager, (2010)

12. P. I. Tugunov, V. F. Novoselov, A.A. Korshak, A.M. Shammazov, Typical calculations for the design and operation of oil depots and oil pipelines (DesignPolygraph Service, Ufa, 2008)

13. Guidelines for evaluating the characteristics of vapor cloud explosions, flash fires, and BLEVEs (A. Inst. of Chem. Eng., cop., New York,1994)

14. H. Schmidli, C. Weihs, The Chemical Engineering Journal and the Biochemical Engineering Journal, 55(1), 61-68 (1998)

15. V.F. Danilov, R.H. Muhutdinov, V.Y. Shurygin, R.M. Timerbaev, The issue of evaporation loss of oil products and possible solutions, 10, 44900-44905 (2015) 